\title{
Environmentally friendly processing of Laminaria ochroleuca for soft food applications with bioactive properties
}

\author{
P. Fradinho ${ }^{1,2} \cdot$ N. Flórez-Fernández ${ }^{1} \cdot$ I. Sousa ${ }^{2} \cdot$ A. Raymundo $^{2} \cdot$ H. Domínguez ${ }^{1}$ • M. D. Torres ${ }^{1}$
}

Received: 12 June 2019 / Revised and accepted: 4 October 2019 / Published online: 6 January 2020

(C) Springer Nature B.V. 2020

\begin{abstract}
Dehydrated Laminaria ochroleuca was processed by autohydrolysis with compressed hot water to extract bioactive compounds. Both the whole algae and individual fractions obtained (solid residue and liquor) were characterised to assess its functional properties for future innovative food applications. Purée-like systems were developed by combining ultrasonic and thermal technologies to maximise the antioxidant capacity and were evaluated by determining colour, texture, rheology, syneresis and the presence of bioactive compounds. Overall, the obtained results indicated that $L$. ochroleuca is a valuable resource that can be used as a whole or taking advantage of its bioactive fractions, in a concept of circular economy and sustainability.
\end{abstract}

Keywords Phaeophyta $\cdot$ Edible brown seaweed $\cdot$ Autohydrolysis $\cdot$ Ultrasounds $\cdot$ Waste $\cdot$ Antioxidants

\section{Introduction}

Widely consumed in Asian countries, the edible brown algae Laminaria ochroleuca (also known as kombu) is mainly valued in Europe through its extracts, which include alginates, bioactives, and pigments (Fernandes et al. 2016). Alginates are commercially used as thickening, gelling, and stabilising agents in food, cosmetic and pharmaceutical industries. This alga also contains fucoidans that reduce the expression of the pro-inflammatory cytokines and have antioxidant, antimicrobial, and antitumoral properties (Flórez et al. 2017). An alternative could be the development of enriched foods with texture appropriate to special groups of the population, since, by $2050,1 / 5$ of the world's population will be over 60 years old, numbers that increase to more than $30 \%$ in Europe (WHO 2015). Brown algae present a chemically and structurally complex cell wall composed of sulphated and branched

Electronic supplementary material The online version of this article (https://doi.org/10.1007/s10811-019-01958-8) contains supplementary material, which is available to authorized users.

M. D. Torres

matorres@uvigo.es

1 Department of Chemical Engineering, Science Faculty, Universidade de Vigo (Campus Ourense), As Lagoas, 32004 Ourense, Spain

2 LEAF - Linking Landscape, Environment, Agriculture and Food, Instituto Superior de Agronomia, Universidade de Lisboa, Tapada da Ajuda, 1349-017 Lisbon, Portugal polysaccharides (fucoidan) associated with proteins and various bound ions (e.g. $\mathrm{Ca}, \mathrm{K}$ ) that limits the efficient extraction of the intracellular and wall compounds (Kadam et al. 2015a).

The use of green technologies such as autohydrolysis (AH) and ultrasound-assisted extraction (UAE) could be valuable tools to extract the functional components of this brown alga, towards its integral valorisation. Water-based extraction is food compatible, non-expensive, and environmentally friendly but has low selectivity with low extraction efficiency (Flórez-Fernández et al. 2019). Namely, AH can be performed operating under high temperature and pressure extraction conditions, changes water properties, allowing solubilisation and depolymerisation of compounds present in the matrix of the seaweed (González-López et al. 2012). Since UAE is a useful technique to enhance extraction of bioactive compounds from brown algae (Kadam et al. 2015b), a combination of both techniques mentioned above could be adequate to enhance the yields of polysaccharides with antioxidant and glycosidase inhibitory activities. UAE could provide an economically feasible technique with potential for scale-up and suited for thermolabile compounds (Wan et al. 2015).

Several studies have been performed with L. ochroleuca extracts (López-Hortas et al. 2018). However, little is known about the whole algae functional properties, apart from some studies regarding its chemical composition (SánchezMachado et al. 2004). In this context, this study aims at the integral valorisation of $L$. ochroleuca using environmentally friendly technologies for the recovery of functional compounds. The chemical and phytochemical properties of the 
obtained extracts as well as the mechanical features of the formulated systems with the whole alga were performed. Potential applications for both extracts and solid residual fractions were outlined.

\section{Materials and methods}

\section{Materials}

Dehydrated Laminaria ochroleuca used as raw material was generously provided by Algas Atlánticas Algamar Co. (Pontevedra, Spain). Algae were milled and sieved in order to obtain particle size ranges below $0.25 \mathrm{~mm}$, and between 0.25 and $2.0 \mathrm{~mm}$. For comparison purposes, two commercial references were used, namely, a purée-like food product aimed for the senior population and fresh pasta with spinach filling.

\section{Subcritical water extraction treatment}

The coarse milled fraction $(0.25-2 \mathrm{~mm})$ L. ochroleuca was subjected to hydrothermal processing (i.e. autohydrolysis) with compressed hot water at $160^{\circ} \mathrm{C}$, using a liquid:solid ratio of $30: 1(\mathrm{w} / \mathrm{w})$, to isolate fucoidan and phlorotannin fractions from the alga (Flórez-Fernández et al. 2019). Four extraction trials were made by placing around $60 \mathrm{~g}$ (d.b.) of algae in a pressurised reactor (Parr 4848, USA), operating at about 7.5 $\mathrm{atm}$. Then, a conventional filtration process was used to separate the solid and liquid phases. Both liquor and solid residue were chemically characterised and used to prepare purée-like mixtures (Fig. 1). The yield of each extraction trial was calculated, as well of severity factor ( $\log$ Ro), i.e. the treatment efficiency, according to Overend and Chornet (1987). The molecular weight cut-off (MWCO) of the liquid phase was performed using an Amicon stirred cell (model 8400, Millipore), using membranes of 100,50 , and $30 \mathrm{kDa}$. All separated fractions $(>100,50-100,30-50$, and $<30)$ were stored at $4{ }^{\circ} \mathrm{C}$ until further use.

\section{Preparation of the purée-like mixtures}

The lowest particle size fraction of $L$. ochroleuca $(<0.25 \mathrm{~mm})$ was used to prepare aqueous dispersions based on the results found for other biopolymer-based materials (e.g. Moreira et al. 2014). Several preliminary trials were conducted to find the optimal preparation conditions: alga sample $(10-20 \% \mathrm{w} / \mathrm{w}$, d.b.) was dispersed in water $\left(40-90{ }^{\circ} \mathrm{C}\right)$, under mechanical stirring (Eurostar Digital, IKA-WERKE) at $300 \mathrm{rpm}$ during 10-30 min. The solid residue from AH was thermally processed in the optimal conditions defined for alga samples. For UAE, an ultrasonic bath (P120H, Elma, Germany) operating at $80 \mathrm{~Hz}$ for $10-30 \mathrm{~min}$ was used and two temperatures (30 and $80{ }^{\circ} \mathrm{C}$ ) were tested (Fig. 1). In order to not disturb the formation of the matrix, the samples were prepared directly in individual sealed glass containers $(35 \mathrm{~mm}$ height, $32 \mathrm{~mm}$ diameter), and left at $5{ }^{\circ} \mathrm{C}$ for $24 \mathrm{~h}$ to ensure full maturation.

\section{Chemical measurements}

\section{Centesimal composition}

Moisture and ash contents (dry basis, d.b.) were determined by gravimetric methods after drying samples at $105 \pm 2{ }^{\circ} \mathrm{C}$ and incinerating $\left(575{ }^{\circ} \mathrm{C}, 6 \mathrm{~h}\right)$, respectively. The nitrogen content was assessed by mass spectrometry using a FlashEA 1112 elemental analyser (Thermo Fisher Scientific). A N-protein conversion factor of 5.38 for brown algae (Lourenço et al. 2002) was used to obtain the protein content (d.b.) of the samples.

\section{Mineral and metals content}

Mineral and metal contents were determined after microwaveassisted (SAVILLEX) acid digestion $\left(80^{\circ} \mathrm{C}, 6 \mathrm{~h}\right) . \mathrm{Ca}, \mathrm{Mg}, \mathrm{K}$, $\mathrm{Na}, \mathrm{P}, \mathrm{As}, \mathrm{Cu}, \mathrm{Cd}, \mathrm{Pb}, \mathrm{Fe}$, and $\mathrm{Zn}$ were analysed by Inductively Coupled Plasma Optical Emission Spectrometry (Optima 4300 DV, Perkin Elmer). Iodine was determined after digestion with tetramethylammonium hydroxide $\left(80^{\circ} \mathrm{C}, 6 \mathrm{~h}\right)$ by Inductively Coupled Plasma Mass Spectrometry (X Series ICP-MS, Thermo Elemental). Mercury determination was made using Cold Vapor Atomic Absorption Spectrometry according to Fernández-Fernández et al. (2007).

\section{Sulphate content}

Sulphate content was determined at least in triplicate by two different methods. For liquid samples, gelatin-barium chloride procedure was used (Dodgson 1961). Absorbance was measured $(500 \mathrm{~nm})$ after incubation at $25^{\circ} \mathrm{C}$, using a standard curve made with $\mathrm{K}_{2} \mathrm{SO}_{4}$. For solid samples, sulphate content was obtained by ionic chromatography method (mobile phase: $3.2 \mathrm{mM}$ sodium carbonate $/ 1 \mathrm{mM}$ sodium bicarbonate at 0.70 $\mathrm{mL} \mathrm{min}^{-1}$ ) as previously reported (Gómez-Ordóñez et al. 2010).

\section{Carbohydrate content}

Alga $(0.25-2 \mathrm{~mm})$ was hydrolysed with $\mathrm{H}_{2} \mathrm{SO}_{4}(72 \% \mathrm{v} / \mathrm{v})$ in a water bath $\left(30^{\circ} \mathrm{C}, 60 \mathrm{~min}\right)$. Subsequently, samples were hydrolysed with sulphuric acid $(4 \% \mathrm{v} / \mathrm{v})$ in an autoclave $\left(121^{\circ} \mathrm{C}, 60 \mathrm{~min}\right)$, and the resulting samples were analysed using High-Performance Liquid Chromatography (HPLC) (Flórez-Fernández et al. 2017). 


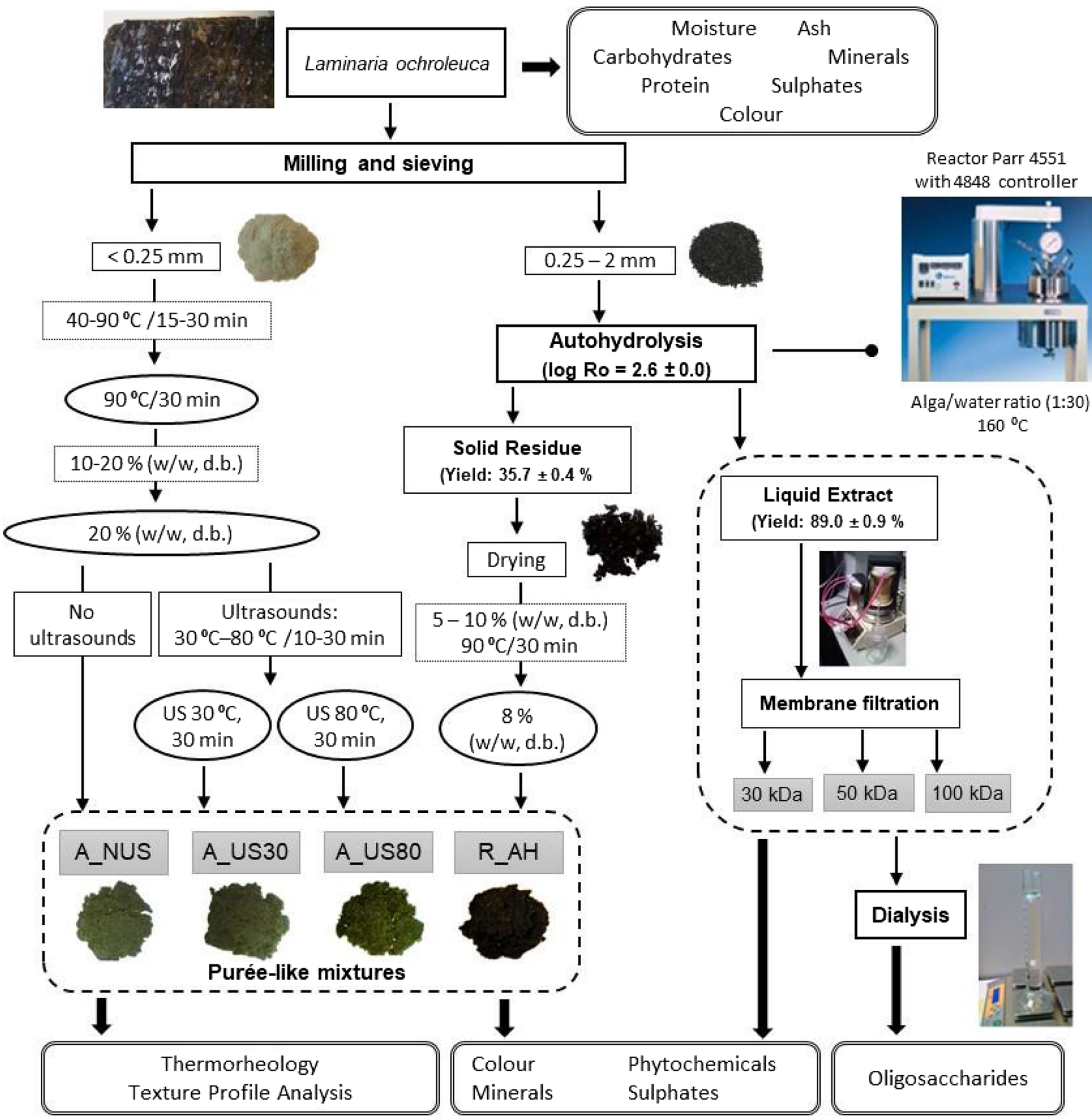

Fig. 1 Schematic representation of the present study, showing the preliminary assayed conditions (squares), the optimal conditions adopted (round), and the characterisation performed (double line). The pictures depict Laminaria ochroleuca and its milled fractions, the

\section{Oligosaccharides determination}

The oligosaccharides in the liquid extract were determined by HPLC. First, the salt content in the samples was reduced to 0.2 $\mu \mathrm{S} \mathrm{cm}{ }^{-1}$ by dialysis using a membrane tubing (Spectra/Por, Float-A-Lyzer G2, MwCo: 100-500 Da). Then, extracts were filtered through $0.45-\mu \mathrm{m}$ membranes. Glucose, fucose, rhamnose, formic acid, and acetic acid were analysed using $300 \times$ autohydrolysis reactor and $\mathrm{AH}$ products (solid residue and liquor), the dialysis procedure and the end-products (purée-like mixtures). A NUS (Alga $20 \%, 90{ }^{\circ} \mathrm{C} / 30 \mathrm{~min}$ ), A_US30 (Alga $20 \%, 90^{\circ} \mathrm{C} / 30 \mathrm{~min}$, UAE 30 ${ }^{\circ} \mathrm{C} / 30 \mathrm{~min}$ ), and A US80 (Alga $20 \%, 90^{\circ} \mathrm{C} / 30 \mathrm{~min}$, UAE $80^{\circ} \mathrm{C} / 30 \mathrm{~min}$ )

7.8 mm Aminex HPX-87H column (BioRad, USA), operating at $60{ }^{\circ} \mathrm{C}$ with sulphuric acid $\left(0.003 \mathrm{M}, 0.6 \mathrm{~mL} \mathrm{~min}^{-1}\right)$ as mobile phase.

\section{High-performance size-exclusion chromatography (HPSEC)}

HPSEC was performed to determine the molar mass distribution of the samples, using two $300 \times 7.8 \mathrm{~mm}$ TSK-Gel 
columns in series (G3000PWXL and G2500PWXL, Tosoh Bioscience, Germany) operating at $70{ }^{\circ} \mathrm{C}$, and a $40 \times 6 \mathrm{~mm}$ PWX-guard column. Milli-Q water with a $0.4 \mathrm{~mL} \mathrm{~min}^{-1}$ flow rate was employed as mobile phase. Dextrans below 80,000 g $\mathrm{mol}^{-1}$ were used as calibration standards.

\section{Instrumental colour}

All measurements were performed using a Minolta CR-400 (Japan) tristimulus colorimeter (five replicates). The colour parameters $\left(L^{*}, a^{*}\right.$, and $\left.b^{*}\right)$ were assessed by CIELAB, at $20 \pm 1{ }^{\circ} \mathrm{C}$ under the same light conditions. $L^{*}$ represents the lightness, $a^{*}$ the redness or greenness degree, and $b^{*}$ the yellowness or blueness degree. The total colour differences $\left(\Delta E^{*}\right)$ between samples were determined according to Expression (1):

$\Delta E^{*}=\left[\left(\Delta L^{*}\right)^{2}+\left(\Delta a^{*}\right)^{2}+\left(\Delta b^{*}\right)^{2}\right]^{1 / 2}$

\section{Texture}

The texture analysis of the samples was conducted on a texturometer TA-XT2 (Stable MicroSystems, UK). Texture profile analysis was done in a double penetration mode using a P0.25S stainless steel probe ( $5 \mathrm{~kg}$ load cell, $12 \mathrm{~mm}$ penetration depth at $1.0 \mathrm{~mm} \mathrm{~s}^{-1}$ crosshead speed). From the texturograms (i.e. force versus time plots), the parameters with the greatest ability to discriminate the samples texture were firmness $(N$, maximum resistance to the penetration of the probe), cohesiveness (how well the system structure withstands penetration), and adhesiveness (N.s, resistance of the material when the probe is recessing). All measurements were performed five times at $20 \pm 1^{\circ} \mathrm{C}$.

\section{Thermorheology}

Small amplitude oscillatory shear testing was conducted at least in duplicate, and storage $\left(\mathrm{G}^{\prime}\right)$ and loss $\left(\mathrm{G}^{\prime \prime}\right)$ moduli were employed to follow the viscoelastic features of purée-like mixtures during the formation process. Suspensions of selected systems were prepared according to the procedure already described and immediately placed into the bottom plate of a controlled stress rheometer (RheoStress 600, Haake, Germany) using cone-plate geometry (diameter $35 \mathrm{~mm}$ and angle $2^{\circ}$ ) and covered with paraffin oil to prevent water loss.

Samples were equilibrated $\left(5 \mathrm{~min}, 25^{\circ} \mathrm{C}\right)$ before rheological testing. Firstly, stress sweep tests $(0.1$ to $100 \mathrm{~Pa})$ were run at $1 \mathrm{~Hz}$, and 25 and $90{ }^{\circ} \mathrm{C}$, and the linear viscoelastic region selected: 0.1 to $35 \mathrm{~Pa}$ for aqueous seaweed solutions and 0.1 to $65 \mathrm{~Pa}$ for purée-like systems. Afterwards, the rheological testing consisted in the following procedure: (1) heating ramp from 25 to $90{ }^{\circ} \mathrm{C}\left(2{ }^{\circ} \mathrm{C} \mathrm{min}-1,1 \mathrm{~Hz}, 15 \mathrm{~Pa}\right)$ to define the sample melting behaviour; (2) temperature setting $\left(90^{\circ} \mathrm{C}, 15\right.$ min); (3) cooling ramp from 90 to $5{ }^{\circ} \mathrm{C}\left(1{ }^{\circ} \mathrm{C} \mathrm{min}{ }^{-1}, 1 \mathrm{~Hz}, 15\right.$ $\mathrm{Pa})$ to follow the viscoelastic evolution with temperature; (4) time sweeps $\left(5^{\circ} \mathrm{C}, 60 \mathrm{~min}, 1 \mathrm{~Hz}, 30 \mathrm{~Pa}\right)$ to corroborate the sample maturation kinetics; (5) frequency sweep from 0.1 to $100 \mathrm{~Hz}\left(5^{\circ} \mathrm{C}, 30 \mathrm{~Pa}\right)$ to assess the mechanical spectrum of the sample.

\section{Bioactive compounds}

Five grams of purée-like mixtures were mixed with $95 \mathrm{~g}$ of distilled water and incubated at $90^{\circ} \mathrm{C}$ for $1 \mathrm{~h}$. After extraction, dispersions were centrifuged $(3000 \times \mathrm{g}, 10 \mathrm{~min}$, room temperature) and the supernatant was used as extract. Liquid samples were used as it is. Dry weight of all extracts was determined in order to express the bioactive compounds in the solid samples. The following spectrophotometric methods were performed in an Evolution 201 UV-Vis Spectrophotometer (ThermoScientific), and all analyses were carried out at least in triplicate.

\section{Scavenging activity}

The ABTS radical cation $\left(\mathrm{ABTS}^{+}\right.$) [2,2-azinobis(3-ethyl-benzothiazoline-6-sulfonate)] scavenging capacity was determined according to Re et al. (1999). Samples $(20 \mu \mathrm{L})$ and TEAC solution $(2 \mathrm{~mL})$ were mixed and incubated $\left(30{ }^{\circ} \mathrm{C}, 6\right.$ min). Phosphate-buffered saline was used as blank. The corresponding absorbance was measured at $734 \mathrm{~nm}$ and the results were expressed as equivalents of Trolox (mM).

\section{Phloroglucinol content}

Phloroglucinol content was determined by the FolinCiocalteu method as reported by Koivikko et al. (2005). Briefly, sample $(500 \mu \mathrm{L})$, Folin-Ciocalteau $(500 \mu \mathrm{L}, 1 \mathrm{~N})$ and $\mathrm{Na}_{2} \mathrm{CO}_{3}(1 \mathrm{~mL}, 20 \% \mathrm{w} / \mathrm{w})$ were mixed and incubated (45 min in the dark) at $25{ }^{\circ} \mathrm{C}$. Afterwards, the mixture was centrifuged $(1600 \times g, 8 \mathrm{~min})$ before measuring the absorbance at $730 \mathrm{~nm}$.

\section{Statistical treatment}

Statistical analysis was performed using one-way ANOVA (Statistica, version 10.0, StatSoft Inc., USA). Whenever the former analysis exhibited differences amongst means, a Tukey test was conducted to differentiate means with $95 \%$ confidence $(p<0.05)$. 


\section{Results and discussion}

\section{Schematic procedure}

The schematic procedure adopted in this study is depicted in Fig. 1. Commercial dried Laminaria ochroleuca was milled and sieved into two particle size fractions. The one with larger particle size $(0.25-2 \mathrm{~mm})$ was used for subcritical water extraction (autohydrolysis) using previously optimised conditions for this alga taking into account the maximum bioactive compounds concentration obtained in the liquid extract (Flórez-Fernández et al. 2019). The smallest particle size fraction $(<0.25 \mathrm{~mm})$ was used to study the effect of different processing treatments on the production of an algae-based structure. Preliminary trials were performed with alga concentrations from 10 to $20 \%$ (w/w, d.b.) and temperatures from 40 to $90{ }^{\circ} \mathrm{C}$ applied for 15 and $30 \mathrm{~min}$. The best conditions$20 \%, 90{ }^{\circ} \mathrm{C}, 30 \mathrm{~min}$ - were selected based on the absence of syneresis and in the formation of a visually compact structure that does not flow. According to Kadam et al. (2015b), UAE can be employed to enhance the extraction of bioactive compounds from seaweed. So, preliminary trials were performed applying UAE at 30 and $80{ }^{\circ} \mathrm{C}$ for 10 and $30 \mathrm{~min}$. Three purée-like mixtures were selected for further analysis: A_NUS (Alga $20 \%, 90^{\circ} \mathrm{C} / 30 \mathrm{~min}$ ), A_US30 (Alga 20\%, 90 ${ }^{\circ} \mathrm{C} / 30 \mathrm{~min}$, UAE $30^{\circ} \mathrm{C} / 30 \mathrm{~min}$ ), and A_US80 (Alga 20\%, 90 ${ }^{\circ} \mathrm{C} / 30 \mathrm{~min}$, UAE $80^{\circ} \mathrm{C} / 30 \mathrm{~min}$ ).

On the other hand, from $\mathrm{AH}$ processing, two fractions were obtained: a liquid extract (liquor) and a solid residue. Traditionally, only the liquid extract is used, and the solid residue discarded. However, this study intends to valorise the entire algae and its AH fractions, in an economically sustainable logic reinforced by the European Community (EC) directive on circular economy (EC 2015a). So, the solid fraction obtained from $\mathrm{AH}$ was characterised and possible applications were studied. The solid residue was dried at $60^{\circ} \mathrm{C}$ for $70 \mathrm{~h}$ for conservation purposes, and then preliminary trials were performed using 5 to $10 \%$ (w/w, d.b.) residue mixed with water and thermally processed in the same way as alga samples. The selected formulation was $8 \%(\mathrm{w} / \mathrm{w}, \mathrm{d} . \mathrm{b}), 90{ }^{\circ} \mathrm{C} /$ 30 min (R_AH). Concerning the liquid AH fraction (liquor), it was purified using membranes with different MWCO: 30 $\mathrm{kDa}, 50 \mathrm{kDa}$, and $100 \mathrm{kDa}$ based on the results previously obtained for other brown seaweeds (Álvarez-Viñas et al. 2019).

\section{Physicochemical and phytochemical characterisation of $L$. ochroleuca and autohydrolysis fractions}

The distinct feature of $L$. ochroleuca is its high ash content (Table 1). The mineral content of seaweeds varies according to seaweed species, but other factors also play a relevant role, like oceanic residence time, the geographical place of harvest, wave exposure, seasonal, annual, environmental and physiological factors, type of processing, and method of mineralisation (Rupérez 2002). Table 1 values are consistent with those reported by Rupérez (2002) and Sánchez-Machado et al. (2004). As compared with other marine species, Laminaria spp. have greater ability to extract minerals from the seawater and hence accumulate high amounts of some elements, such as magnesium, calcium, and iodine (Kim and Bhatnagar 2011), presenting here an opportunity for the development of food products with low sodium content as already reported for beef patties with Undaria pinnatifida (López-López et al. 2011).

Regarding dried $L$. ochroleuca protein content, the value found is consistent with Sanchez-Machado et al. (2004) results for the same alga species $(7.49 \%$, d.b.). Generally, protein content of seaweeds is low when compared with polysaccharides and polyphenols; therefore, they are rarely valued for the functional properties of their proteins (Conde et al. 2013). Amongst seaweeds, Phaeophyta present the lowest protein values $(6.4-19.8 \%$, d.b.), although it can vary according to the factors described earlier and the analytical methods used (Cěrná 2011). It is noteworthy that the obtained value for the dried seaweed is lower than the sum of the AH fractions, which can be due to low extraction efficiency in alga sample because of its complex polysaccharide cell wall structure. During subcritical water extraction, proteins are degraded and the water soluble peptides could be extracted (Castro-Puyana et al. 2013) and therefore be present in the $\mathrm{AH}$ liquor.

Regarding the solid residue obtained from $\mathrm{AH}$, it still maintains some valuable compounds, namely minerals $(\mathrm{K}, \mathrm{Ca}$, and $\mathrm{Na}$ ). In brown algae, sulphate is a component of fucoidan, a sulphated polysaccharide present in the cell wall of these organisms that protect the algae from desiccation (Rupérez 2002). The complex composition of fucoidans remains uncertain despite the numerous studies about their composition and chemical structure (Martínez-Hernández et al. 2017). It is noteworthy that $\mathrm{AH}$ processing promoted the solubilisation of the sulphates since liquor shows a higher content than that of dried Laminaria.

Apart from bioaccumulating essential minerals such as $\mathrm{Ca}$, $\mathrm{Mg}, \mathrm{Fe}$, and I, seaweeds can also concentrate other elements that can represent a health risk for consumers, namely $\mathrm{Pb}, \mathrm{Cd}$, and As. Indeed, due to the adsorption capacity of seaweeds, several studies have been conducted aiming for wastewater treatment and pollution control (Lodeiro et al. 2005). East Asian cultures have traditionally exploited Laminaria spp. for food and medicine, and this alga is even listed in the Chinese pharmacopoeia (Kim and Bhatnagar 2011). Unexpectedly, in these countries, which are responsible for most seaweeds' production and consumption as human food, no specific limits have been established regarding its toxic metals content (Circuncisão et al. 2018). In Western countries, 
Table 1 Chemical composition of L. ochroleuca and autohydrolysis products

\begin{tabular}{|c|c|c|c|c|}
\hline & & L. ochroleuca & Solid residue & Liquor \\
\hline & Moisture $\left(\mathrm{g}(100 \mathrm{~g})^{-1}\right)$ & $9.20 \pm 0.07$ & $3.63 \pm 0.08$ & $97.81 \pm 0.01$ \\
\hline & $\operatorname{Ash}\left(g(100 g)^{-1}, d . b\right)$ & $35.01 \pm 0.31$ & $17.54 \pm 0.07$ & $10.28 \pm 0.16$ \\
\hline & Protein $\left(g(100 g)^{-1}\right.$, d.b $)$ & $9.21 \pm 0.12$ & $15.85 \pm 0.31$ & $5.61 \pm 0.02$ \\
\hline & Sulphates $\left(\mathrm{g}(100 \mathrm{~g})^{-1}\right.$, d.b $)$ & $2.21 \pm 0.10$ & $2.11 \pm 0.08$ & $14.54 \pm 2.2$ \\
\hline \multirow[t]{7}{*}{ Minerals $\left(\mathrm{mg} \mathrm{kg}^{-1}\right)$} & Calcium $(\mathrm{Ca})$ & 7154 & 14,393 & 3441 \\
\hline & Potassium (K) & 107,314 & 44,178 & 175,156 \\
\hline & Magnesium (Mg) & 5032 & 3134 & 6310 \\
\hline & Sodium (Na) & 29,070 & 11,309 & 46,956 \\
\hline & Phosphorus (P) & 1872 & 850 & 2628 \\
\hline & Iodine (I) & 4130 & 1600 & 6760 \\
\hline & Zinc $(\mathrm{Zn})$ & n.d. & 40 & n.d. \\
\hline \multirow[t]{6}{*}{ Heavy metals ( $\mathrm{mg} \mathrm{kg}^{-1}$ ) } & Arsenic (As) & 41.3 & 30.6 & 43.2 \\
\hline & Cadmium (Cd) & 0.7 & 1.0 & 0.7 \\
\hline & Copper $(\mathrm{Cu})$ & $<1$ & 2.7 & $<1$ \\
\hline & Iron $(\mathrm{Fe})$ & 22.1 & 56 & 3.5 \\
\hline & Lead $(\mathrm{Pb})$ & $<2.2$ & $<2$ & $<2.3$ \\
\hline & Mercury (Hg) & n.d. & 0.065 & n.d. \\
\hline
\end{tabular}

Data are shown as mean \pm standard deviation, in dry basis. All data without standard deviations exhibited standard deviations below $2 \%$

there has been an increasing interest in algae research and food development using seaweeds (e.g. López-López et al. 2011; del Olmo et al. 2018). Probably to its gastronomy tradition of using seaweeds for human consumption, on the 1990s, France sets a recommendation on the maximum heavy metal limits: $3 \mathrm{mg} \mathrm{kg}^{-1}$ As, $0.1 \mathrm{mg} \mathrm{kg}^{-1} \mathrm{Hg}, 5 \mathrm{mg} \mathrm{kg}^{-1} \mathrm{~Pb}$ (Benoit 2016; AFSSA 2009; Circuncisão et al. 2018). On a regulatory point of view, the Europe legislation only sets maximum allowed levels of $\mathrm{Cd}\left(3 \mathrm{mg} \mathrm{kg}^{-1}\right)$ and $\mathrm{Pb}\left(3 \mathrm{mg} \mathrm{kg}^{-1}\right)$ in foodstuffs (Reg. CE 629/2008). This issue is on today's agenda, so in recent years, there has been some efforts made towards a European standardisation on this matter. The European Commission set a recommendation for monitoring the presence of arsenic in food, between 2016 and 2018 to enable an accurate estimation of As exposure (EC 2015b). The FAO/ WHO Joint Expert Committee on Food Additives (JECFA) also established for cadmium limits for assumed safe intakes, the provisional tolerable weekly dose (PTWI, $\mu \mathrm{g} \mathrm{kg}^{-1}$ of body weight in a week) that an adult man can absorb without health damage. These levels have been adjusted throughout the years, and in 2011 were set in $2.5 \mu \mathrm{g}$ of cadmium $\mathrm{kg}^{-1}$ body weight in order to ensure a high level of protection of consumers (EFSA 2012).

Our results show that of the analysed heavy metals, only arsenic levels may be of concern in L. ochroleuca and its AH fractions, but since a speciation of the chemical forms of arsenic was not performed in this study, only the total arsenic content is presented. Although some studies show that heavy metal levels of brown algae can be reduced by application of AH (e.g. Saravana et al. 2016), we did not observed this tendency. Moreover, during seaweed metabolic process, inorganic As can be converted into organic forms, less harmful to human health (Taylor et al. 2017).

As already mentioned, membrane technology was used to obtain purified fractions from the $\mathrm{AH}$ liquor. Both $\mathrm{AH}$ liquor and the membrane fractions were characterised in terms of antioxidant activity (Table 2). The most relevant feature is that the fractioning of AH liquor resulted in a significant $(p<0.05)$ increase in phlorotannin and sulphate contents that showed an increasing trend with decreasing MWCO although without statistical significance. These values are comparable with those obtained by microwave hydrogravity (MHG) from L. ochroleuca (López-Hortas et al. 2018). Concerning the scavenging activity, the highest MWCO tested fraction (> $100 \mathrm{kDa}$ ) exhibited the largest values. This behaviour nicely matches those reported for other brown seaweeds (Sargassum muticum) processed by membranes (Álvarez-Viñas et al. 2019), although the enhancement found here was much lower than that identified in S. muticum. A decreasing trend in this parameter was identified to lower membrane size pore, but not with the phenolic content. Even though, the values obtained here were higher than those obtained for the same alga (L. ochroleuca) using other green technology as microwave hydrogravity (López-Hortas et al. 2018), reinforcing the formation of novel bioactive compounds using $\mathrm{AH}$.

Regarding the colour parameters of L. ochroleuca, $\mathrm{AH}$ products and purified fractions (Table S3), there are noticeable differences between $L$. ochroleuca milled fractions, with smaller particle size fraction being lighter, due mainly to the $L^{*}$ value, which is directly related to the surface area 
Table 2 Antioxidant activity of AH liquor and purified fractions from Laminaria ochroleuca

\begin{tabular}{llll}
\hline & Phlorotannins (mg PGE g ${ }^{-1}$ extract d.b) & ABTS (mg Trolox g ${ }^{-1}$ extract d.b) & Sulphates (mg g ${ }^{-1}$ extract d.b) \\
\hline Liquor & $4.65 \pm 0.10^{\mathrm{b}}$ & $7.05 \pm 0.01^{\mathrm{b}}$ & $145.4 \pm 2.2^{\mathrm{b}}$ \\
R100 & $5.72 \pm 0.03^{\mathrm{a}}$ & $7.91 \pm 0.01^{\mathrm{a}}$ & $417.9 \pm 8.7^{\mathrm{a}}$ \\
R50 & $6.05 \pm 0.32^{\mathrm{a}}$ & $5.42 \pm 0.01^{\mathrm{c}}$ & $103.5 \pm 0.8^{\mathrm{c}}$ \\
R30 & $6.18 \pm 0.53^{\mathrm{a}}$ & $1.81 \pm 0.01^{\mathrm{d}}$ & $88.4 \pm 5.0^{\mathrm{d}}$ \\
P30 & $5.62 \pm 0.04^{\mathrm{a}}$ & $1.55 \pm 0.01^{\mathrm{e}}$ & $73.3 \pm 3.1^{\mathrm{e}}$ \\
\hline
\end{tabular}

Data are presented as mean \pm standard deviation. Different superscript letters in a column show significantly different data values at $p \leq 0.05$ level

differences. The $\Delta E^{*}$ between purified fractions and $\mathrm{AH}$ liquor ranges from 3.4 to 6.4 , indicating that, apart from R100, the mentioned colour differences are detected by normal human vision (Castellar et al. 2006). The brownish colour of AH liquor is probably due to the formation of new compounds by Maillard and caramelization reactions, which could be favoured by extraction conditions, namely high temperature. These new compounds can possess antioxidant activity as reported by previous studies with plants (e.g. Rosmarinus officinalis L., Thymus vulgaris), microalgae (Chlorella vulgaris), and seaweeds (e.g. Porphyra spp., Undaria pinnatifida, Sargassum muticum, Saccharina japonica) (Plaza et al. 2010; Saravana et al. 2016).

\section{Molecular mass distribution}

From the HPSEC spectra of L. ochroleuca AH liquor and their corresponding fractions (Figure S1), it is clearly observed that all systems exhibited high molecular weight (> $80 \mathrm{kDa})$. Liquor, $>100 \mathrm{kDa}$ and $50-100 \mathrm{kDa}$ featured a similar profile. In the latter two fractions, the use of the membranes led to concentrate polymers with higher molecular weight. In the membranes with the lowest pore size, it was observed depolymerization of the polysaccharides presents in the liquor, with peaks close to $80 \mathrm{kDa}$. These two trends are consistent with phytochemical results.

\section{Oligosaccharides}

The maximum fucose oligosaccharide content (9.84 g (100 g) ${ }^{-1}$ extract) was found in the $>100 \mathrm{kDa}$ fraction (Fig. 2) matching with the maximum sulphate content $\left(417.9 \mathrm{mg} \mathrm{g}^{-1}\right.$ extract) (Table 2). The fucose content was followed by glucose, galactose, mannose, and xylose oligosaccharides in the higher membranes. In contrast, the lower cut-off membranes exhibited a different trend. These results are consistent with the phytochemical results previously explained.

In a recent study, Flórez-Fernandez et al. (2019) performed autohydrolysis at temperatures between $120-220{ }^{\circ} \mathrm{C}$ with L. ochroleuca. These authors found that the oligosaccharides content continued to increase up to $180^{\circ} \mathrm{C}$, when they start to decrease, probably due to caramelization and Maillard reactions (Saravana et al. 2016).

\section{Characterisation of purée-like mixtures}

\section{Texture measurements}

The texture profile of the purée-like mixtures and the commercial samples (pasta filling and elderly food) are depicted in Fig. 3 (texture parameters extracted, Table S2). The texture profiles of the alga systems vary according to the UAE treatment (Fig. 3a). As already mentioned, UAE results in the release of bioactive compounds into the medium. This fact translates in a significant adhesiveness gain for the system from -0.31 to -0.92 N.s. This could be associated with a release of phospholipids or glycoproteins from the algae cell wall. However, the same treatment combined with temperature (A_US80) originated a product significantly less firm and adhesive. This thermal behaviour is consistent with that found for other food matrices, where denaturation and structural changes of proteins were suggested as responsible for the adhesiveness decrease (Pérez-Santaescolástica et al. 2018). These authors also indicated that the combined thermal and ultrasonic cavitation effect could cause loosening of the molecular structure and reduction of molecular nodes.

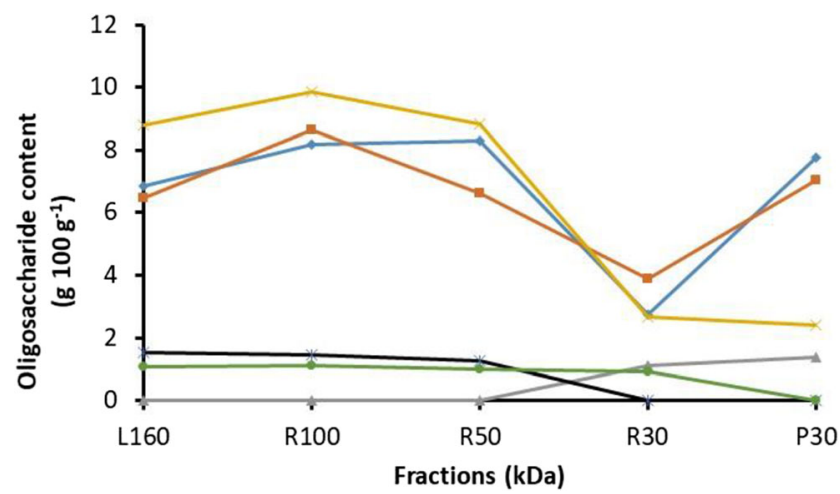

Fig. 2 Oligosaccharide and sulphate contents of liquid extract obtained from autohydrolysis (L160) and the corresponding fractions. Symbols: $\longrightarrow$ O-Glucose; $=\mathrm{O}-\mathrm{Ga}+\mathrm{Xy}+\mathrm{Mn} ;=\mathrm{O}-\mathrm{Rhamnose}=\mathrm{O}-$ Fucose; — Formic Groups; — Acetyl Groups 
Fig. 3 Texture profile analysis (TPA) for the different tested systems a prepared with

L. ochroleuca brown seaweed (i.e. A_NUS, A_US30, A_US80, R_AH) as well as b those commercially available (i.e. Pasta filling and Elderly food). A_NUS (Alga $20 \%, 90^{\circ} \mathrm{C} / 30 \mathrm{~min}$ ), A_US30 (Alga $20 \%, 90^{\circ} \mathrm{C} / 30$ $\left.\min , \mathrm{UAE} 30^{\circ} \mathrm{C} / 30 \mathrm{~min}\right)$, and A US80 (Alga $20 \%, 90^{\circ} \mathrm{C} / 30$ min, UAE $\left.80^{\circ} \mathrm{C} / 30 \mathrm{~min}\right)$ (a)
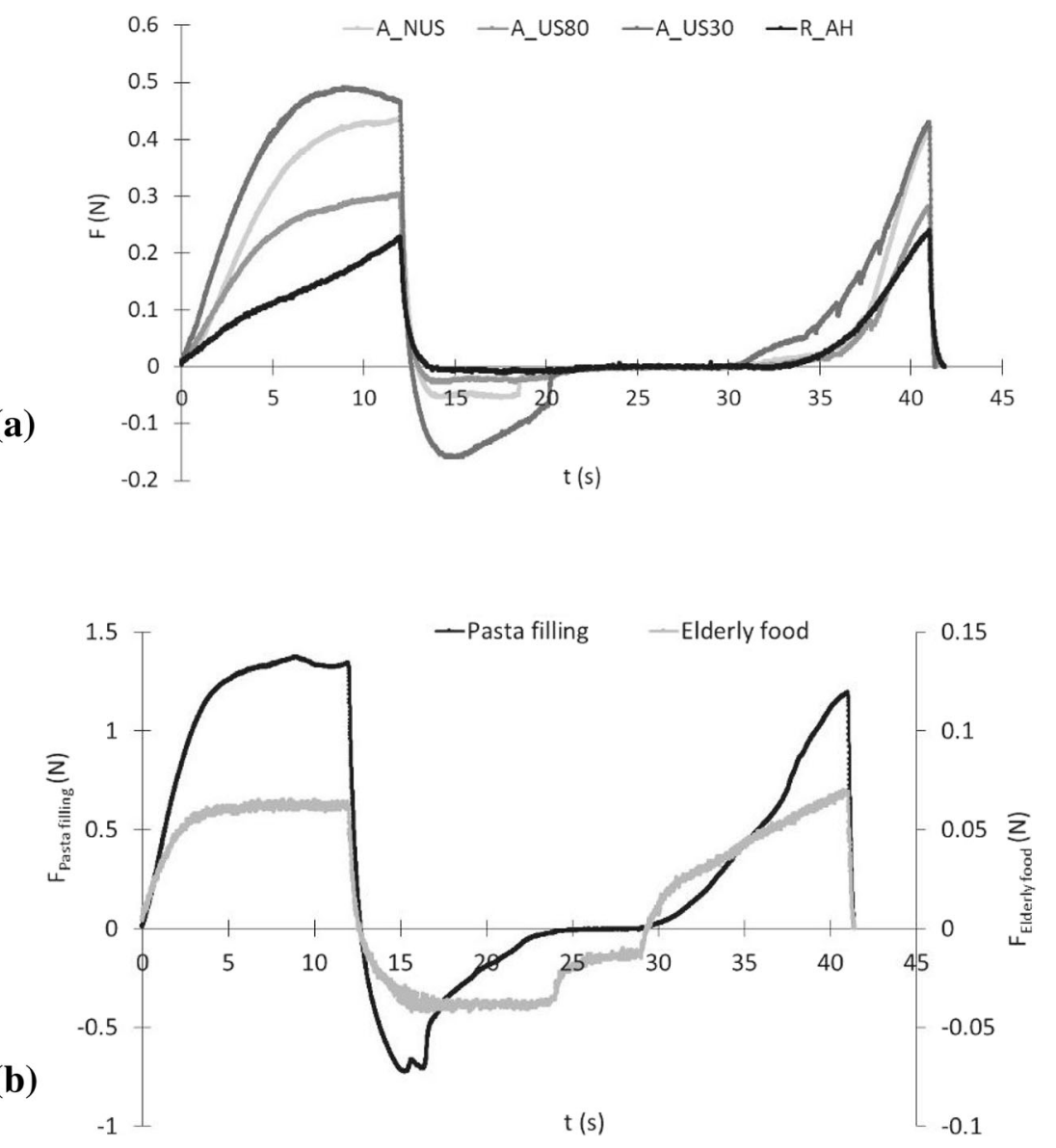

Comparing the texture profile of the purée-like systems developed with the commercial food products selected (Fig. 3), A_US30 is the system that most resembles the pasta filling. Although some differences are observed, especially in their firmness and adhesiveness values (Table S2), it should be pointed out that the systems developed are not finished products, but systems consisting of only alga/residue and water. According to a Finnish Project Report on Food for Seniors (Heiniö et al. 2014), the textures between soft and semi-hard were the most preferred by senior consumers, indicating that some but not too big textural challenges are appreciated. Furthermore, they prefer salty dishes, which can point to the development of the type of products suggested in the present study.

The EC regulation is absent about the use of AH solid residue for food applications. However, the sensorial perception, namely the characteristic aroma, could be an issue. We suggest the use of this raw material in non-food applications, for instance, cosmetic or personal care products.

\section{Thermorheological measurements}

At the beginning of the heating process, all samples showed a predominantly viscous behaviour, with $\mathrm{G}^{\prime \prime}$ being higher than $\mathrm{G}^{\prime}$ (Fig, 4a). Although practically no differences related to the sample structure are observed, R_AH presented a slightly different heating profile than the alga samples. At around $35{ }^{\circ} \mathrm{C}$, there is a crossing of the moduli for all samples that suggests sample structuration due to water uptake from the protein, fibre (Laminaria japonica: $50.7 \mathrm{~g}(100 \mathrm{~g})^{-1}$ ) or sugars present in the sample (Moreira et al. 2014).

During the cooling process (Fig. 4b), all samples showed a linear increase of both viscoelastic moduli, revealing an increase in structuring as the temperature lowers. The three alga samples showed a similar profile, and different from $\mathrm{R}_{-} \mathrm{AH}$, where the rate of structuring is not so pronounced $\left(\mathrm{G}^{\prime}{ }_{90^{\circ} \mathrm{C}} \rightarrow \mathrm{G}_{5^{\circ} \mathrm{C}}\right.$ : $\left.200-600 \mathrm{~Pa}\right)$, whereas for the other samples $\mathrm{G}^{\prime}$ increases more than 60 times. Fucoidan, the main polysaccharide of $L$. ochroleuca, is very soluble once extracted and the solubility is related to the level of branching, depending on the content of sulphate groups (Cunha and Grenha 2016). During AH processing, algae polysaccharides, namely fucoidan, laminarin, alginate, and its fractions, are released into the liquid extract (Wan et al. 2015), what explains why in R_AH the degree of structuring is lower than in the alga samples, where these polysaccharides are still present. Although fucoidan does not develop highly viscous solutions 
Fig. 4 Thermorheology of tested systems prepared with

L. ochroleuca brown seaweed: a temperature profiles on heating ( 25 to $90{ }^{\circ} \mathrm{C}$ at $2{ }^{\circ} \mathrm{C} \mathrm{min}^{-1}$ ) and $\mathbf{b}$ cooling $\left(90\right.$ to $5^{\circ} \mathrm{C}$ at $\left.1^{\circ} \mathrm{C} \mathrm{min}^{-1}\right)$, c time sweep $\left(5^{\circ} \mathrm{C}\right), \mathbf{d}$ frequency sweep $\left(25^{\circ} \mathrm{C}\right)$. Symbols: circles (A_NUS), diamonds (A_US80), squares (A_US30), triangles (R_AH), closed (storage modulus, $\mathrm{G}^{\prime}$ ), open (loss modulus, G"), A_NUS (Alga $\left.20 \%, 90{ }^{\circ} \mathrm{C} / 30 \mathrm{~min}\right)$, A_US30 (Alga $20 \%, 90^{\circ} \mathrm{C} / 30 \mathrm{~min}, \mathrm{UAE}$ $30^{\circ} \mathrm{C} / 30 \mathrm{~min}$ ), and A_US80 (Alga $20 \%, 90{ }^{\circ} \mathrm{C} / 30 \mathrm{~min}, \mathrm{UAE}$ $\left.80^{\circ} \mathrm{C} / 30 \mathrm{~min}\right)$ (a)

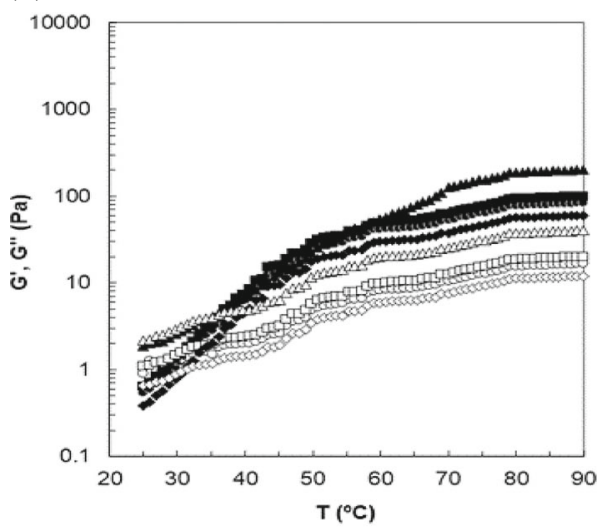

(c)

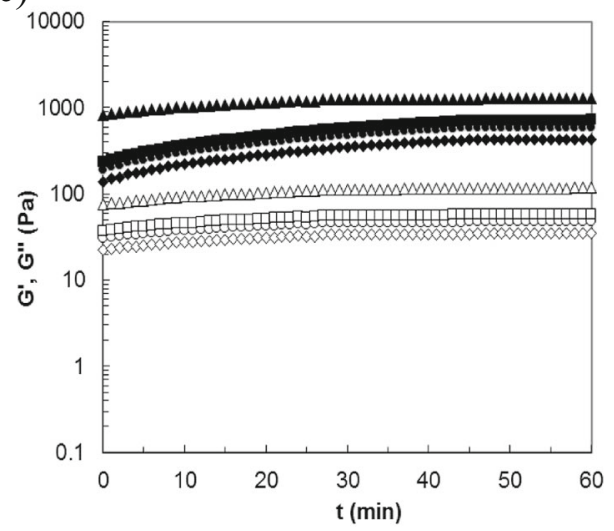

(b)

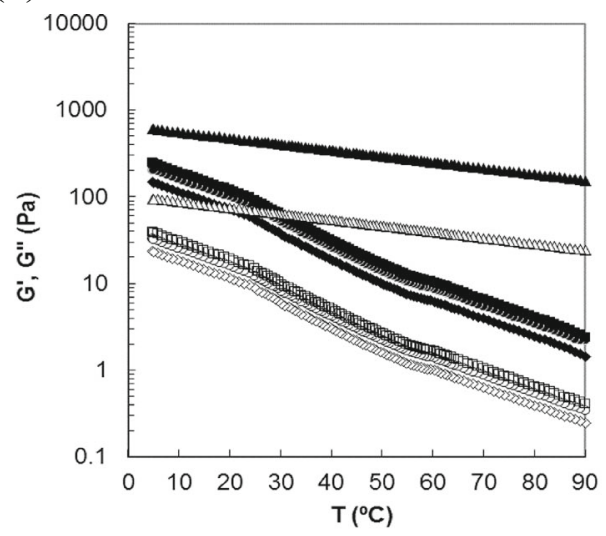

(d)

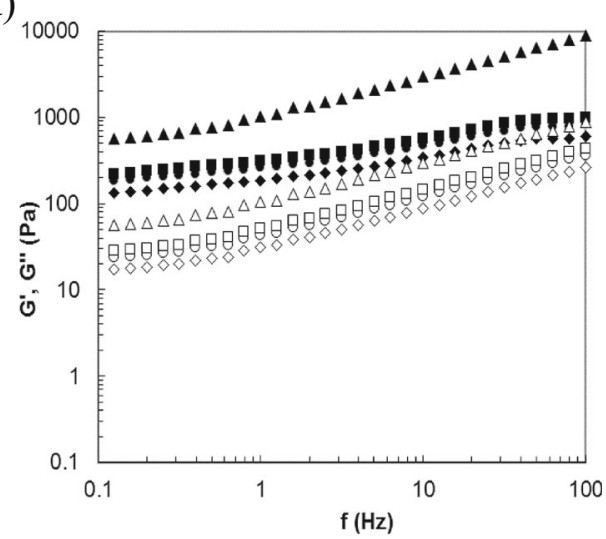

(Rupérez 2002), in fact, it produces aqueous solutions of low apparent viscosity with shear-thinning flow behaviour; alginate forms very viscous solutions (Flórez-Fernández et al. 2019) that can be responsible for the differences obtained between samples.

Regarding the maturation kinetics (Fig. 4c) of the systems, R_AH is almost instantaneously matured after the cooling process, whereas the alga samples take about $45 \mathrm{~min}$ to attain full maturation. At this point, it is clear that A_US80 shows a slightly weak structure than the other samples, indicating that the temperature in the UAE (and not the UAE) is responsible for the weakening of the structure of this sample. At $80^{\circ} \mathrm{C}$, the proteins in this sample are already fully denatured and not able to form entanglements that result in structural reinforcement.

As depicted in the mechanical spectra (Fig. 4d), these material structure is consistent with pastes, i.e. purée-like systems, what can be explained by the swelling $(10.20 \pm 0.37$ $\mathrm{mL} \mathrm{g}^{-1}$, d.b), and water absorption capacity $\left(8.93 \pm 0.52 \mathrm{~g} \mathrm{~g}^{-1}\right.$, d.b) of Laminaria (Gómez-Ordóñez et al. 2010). These values are similar to those from Psyllium husk, well-known for its water uptake capacity (Raymundo et al. 2014).

Apart from processing conditions in texture and rheology measurements, the results of the mechanical spectra are in agreement with the ones from texture analysis (Fig. 3a).
Although R_AH presents higher viscoelastic modulli in the mechanical spectrum, it is highly frequency dependent (especially at higher frequency values), indicating a less structured material. This reflects the more cohesive and less firm structure of R_AH when compared with alga samples (Table S1).

\section{Colour and syneresis}

As expected, in terms of colour (Table S3), R_AH is distinctively different from the other systems. It presents a darker brownish colour, whereas the algae systems are greener. The $\Delta E^{*}$ between the other alga mixtures ranges from 1.26 to 2.45 , below the threshold of normal human vision (Castellar et al. 2006). Although none of the samples presented syneresis, R_AH showed a slight tendency for syneresis with time (not measured). Both of these parameters could be of interest in future applications.

\section{Bioactive compounds measurements}

Purée-like mixtures exhibited a wide range of sulphate content (A_NUS: $1.93 \pm 0.6 \mathrm{~g}(100 \mathrm{~g})^{-1}$, d.b.) increasing with UAE (A_US30: $4.51 \pm 1.3 \mathrm{~g}(100 \mathrm{~g})^{-1}$, d.b.) and AH (R_AH: 13.43 $\pm \overline{4} .7 \mathrm{~g}(100 \mathrm{~g})^{-1}$, d.b.) processing. Note that the sulphate 
content of A_US80 was $2.46 \pm 0.60 \mathrm{~g}(100 \mathrm{~g})^{-1}$, d.b., lower than all alga pretreated systems. This suggests that some interferences could take place with biopolymers as gelling starch fractions or denatured proteins at $80{ }^{\circ} \mathrm{C}$. In general, the sulphate content of the raw material (Table 1), when compared with the content developed in the purée-like mixtures, exhibited a huge increase. This is probably due to both processing methodologies that favour the solubilisation of compounds and their release into the medium, behaviour consistent with the observed for other brown seaweeds (FlórezFernández et al. 2017).

Concerning phlorotannin content, the purée-like mixture pretreatments could allow the formulation of final products with the seaweed or solid residue from $\mathrm{AH}$ with values in the same order of magnitude as those obtained in $\mathrm{AH}$ liquor (4.65 $\mathrm{mg} \mathrm{g}^{-1}$ extract), reinforcing the functional potential of the developed matrices. However, the antioxidant activity of these systems could be increased by replacing the water with the AH liquor, since subcritical water extraction allows the formation of new compounds with antioxidant capacity, as already mentioned and reported by several authors (Plaza et al. 2010; González-López et al. 2012). For this purpose, Shibata et al. (2008) suggest that a complex of crude phlorotannins and soybean protein may be useful as a new functional foodstuff with antioxidant and anti-inflammatory activity. To our knowledge, there are no studies with the whole alga processed in the way proposed in this study. These puréelike mixtures could be suited for food applications as a source of minerals or may serve as a food supplement to help meet the recommended daily intakes of some minerals and trace elements (Rupérez 2002). Ageing is also associated with the insufficient intake of micronutrients, which leads to global nutritional deficiency. In this way, the intake of foods rich in vitamins and minerals is recommended for this age group population. Overall, this work represents a preliminary study where proposed purée-like mixtures could be an attractive alternative for specific target population groups. Anyway, before developing any final product formulation, the heavy metal content as arsenic present in the algae formulation should be further studied and surveyed. Even though, previous works (e.g. García-Sartal et al. 2013) indicated that heavy metals present in L. ochroleuca exhibited a negligible bioavailability after cooking.

\section{Conclusions}

This approach based on the integral use of $L$. ochroleuca is an alternative to the current production process of chemicals from seaweed focused on a single product (e.g. alginate) and to the more recent cascade biorefinery. Besides, the incorporation of whole algae promotes the simultaneous presence of different components (dietary fibre, protein, minerals, vitamins, carotenoids, phlorotannins, etc.), with both health-beneficial effects and technological advantages. Future studies are being performed to evaluate the effect of the incorporation of the algae mixtures with gelling agents to expand the spectra of applications.

Funding information This work received support the Spanish Ministry of Economy and Competitiveness (CTM2012-38095 and CTM201568503-R). M.D.T. thanks the Spanish Ministry of Economy and Competitiveness for her postdoctoral grant (IJCI-2016-27535). N.F.F. thanks the Xunta de Galicia for her postdoctoral grant (ED481B 2018/071). P.F. received PhD grant from the Universidade de Lisboa $(\mathrm{C} 0144 \mathrm{M})$ and ERASMUS+ grant. The authors also are grateful to the Fundação para a Ciência e a Tecnologia (Portugal) through the research unit UID/AGR/04129/2013 (LEAF).

\section{References}

AFSSA (2009) Opinion of the French Food Safety Agency on the recommended maximum inorganic arsenic content of laminaria and consumption of these seaweeds in light of their high iodine content. AFSSA Request no. 2007-SA-0007

Álvarez-Viñas M, Flórez-Fernández N, González-Muñoz MJ, Domínguez H (2019) Influence of molecular weight on the properties of Sargassum muticum fucoidan. Algal Res 38:101393

Benoit M (2016) Seaweed Standards for food and cosmetics. Seagriculture $-5^{\text {th }}$ International Seaweed Conference. Aveiro, Portugal. https://seagriculture.eu/wp-content/upload folders/ seagriculture.eu/2016/10/2.3-Maud-Benoit-Seaweed-standards-forfood-and-cosmetics.pdf

Castellar MR, Obón JM, Fernández-López JA (2006) The isolation and properties of a concentrated red-purple betacyanin food colorant from Opuntia stricta fruits. J Sci Food Agric 86:122-128

Castro-Puyana M, Herrero M, Mendiola JÁ, Ibáñez E (2013) Subcritical water extraction of bioactive components from algae. In: Domínguez $\mathrm{H}$ (ed) Functional ingredients from algae for foods and nutraceuticals. Woodhead Publishing, Cambridge, pp 534-560

Cěrná M (2011) Seaweed proteins and amino acids as nutraceuticals. In: Kim S-K (ed) Advances in food and nutrition research. Elsevier, Amsterdam, pp 297-312

Circuncisão AR, Catarino MD, Cardoso SM, Silva AMS (2018) Minerals from macroalgae origin: health benefits and risks for consumer. Mar Drugs 16:400

Conde E, Balboa EM, Parada M (2013) Algal proteins, peptides and ainoacids. In: Domínguez H (ed) Functional ingredients from algae for foods and nutraceuticals. Woodhead Publishing, Cambridge, pp $135-180$

Cunha L, Grenha A (2016) Sulfated seaweed polysaccharides as multifunctional materials in drug delivery applications. Mar Drugs 14:42

del Olmo A, Picon A, Nuñez M (2018) Cheese supplementation with five species of edible seaweeds: effect on microbiota, antioxidant activity, colour, texture and sensory characteristics. Int Dairy J 84:36-45

Dodgson KS (1961) Determination of inorganic sulphate in studies on the enzymatic and non-enzymatic hydrolysis of carbohydrate and other sulphate esters. Biochem J 78:312-319

EFSA (2012) Cadmium dietary exposure in the European population. Scientific Report of EFSA. EFSA J 10:2551 
European Commission (2008) Commission Regulation (EC) $\mathrm{N}^{\circ}$ 629/ 2008 amending Regulation (EC) $\mathrm{N}^{\circ} 1881 / 2006$ setting maximum levels for certain contaminants in foodstuffs. Brussels, Official Journal of the European Union 176:6-9

European Commission (2015a) Closing the loop - an EU action plan for the circular economy. In: Brussels, $\operatorname{COM}(2015) 614$. Journal of the European Union, Official

European Commission (2015b) Commission Recommendation 2015/ 1381 on the monitoring of arsenic in food. Brussels, Official Journal of the European Union 213:9-10

Fernandes F, Barbosa M, Oliveira AP, Azevedo IC, Sousa-Pinto I, Valentão P, Andrade PB (2016) The pigments of kelps (Ochrophyta) as part of the flexible response to highly variable marine environments. J Appl Phycol 28:3689-3696

Fernández-Fernández AM, Moreda-Piñeiro A, Bermejo-Barrera P (2007) On-line preconcentration cold vapour atomic absorption spectrometry for the determination of trace mercury in edible seaweeds. J Anal At Spectrom 22:573-577

Flórez N, Gonzalez-Muñoz MJ, Ribeiro D, Fernandes E, Dominguez H, Freitas M (2017) Algae polysaccharides' chemical characterization and their role in the inflammatory process. Curr Med Chem 24:149175

Flórez-Fernández N, López-García M, González-Muñoz MJ, LópezVilariño JM, Domínguez H (2017) Ultrasound-assisted extraction of fucoidan from Sargassum muticum. J Appl Phycol 29:1553-1561

Flórez-Fernández N, Torres MD, González-Muñoz MJ, Domínguez H (2019) Recovery of bioactive and gelling extracts from edible brown seaweed Laminaria ochroleuca by non-isothermal autohydrolysis. Food Chem 277:353-361

García-Sartal C, Barciela-Alonso MC, Moreda-Piñeiro A, BermejoBarrera P (2013) Study of cooking on the bioavailability of As, $\mathrm{Co}, \mathrm{Cr}, \mathrm{Cu}, \mathrm{Fe}, \mathrm{Ni}, \mathrm{Se}$ and $\mathrm{Zn}$ from edible seaweed. Microchem J 108:92-99

Gómez-Ordóñez E, Jiménez-Escrig A, Rupérez P (2010) Dietary fibre and physicochemical properties of several edible seaweeds from the northwestern Spanish coast. Food Res Int 43:2289-2294

González-López N, Moure A, Domínguez H (2012) Hydrothermal fractionation of Sargassum muticum biomass. J Appl Phycol 24:15691578

Heiniö R-L, Pentikäinen S, Rusko E, Peura-Kapanen L (2014) Food for seniors - final report. National Consumer Research Centre, VTT Technology 202. ISBN 978-951-38-8200-6. http://www.vtt.fi/publications/index.jsp. Accessed 27 December 2018.

Kadam SU, O’Donnell CP, Rai DK, Hossain MB, Burgess CM, Walsh D, Tiwari BK (2015a) Laminarin from Irish brown seaweeds Ascophyllum nodosum and Laminaria hyperborea: ultrasound assisted extraction, characterization and bioactivity. Mar Drugs 13: $4270-4280$

Kadam SU, Tiwari BK, Smyth TJ, O’Donnell CP (2015b) Optimization of ultrasound assisted extraction of bioactive components from brown seaweed Ascophyllum nodosum using response surface methodology. Ultrason Sonochem 23:308-316

Kim S-K, Bhatnagar I (2011) Physical, chemical, and biological properties of wonder kelp - Laminaria. In: Kim S-K (ed) Advances in food and nutrition research. Elsevier, Amsterdam, pp 85-96

Koivikko R, Loponen J, Honkanen T, Jormalainen V (2005) Contents of soluble, cell-wall-bound and exuded phlorotannins in the brown alga Fucus vesiculosus, with implications on their ecological functions. J Chem Ecol 31:195-212

Lodeiro P, Cordero B, Barriada JL, Herrero R, Sastre de Vicente ME (2005) Biosorption of cadmium by biomass of brown marine macroalgae. Bioresour Technol 96:1796-1803
López-Hortas L, Gannon L, Moreira R, Chenlo F, Domínguez H, Torres MD (2018) Microwave hydrodiffusion and gravity (MHG) processing of Laminaria ochroleuca brown seaweed. J Clean Prod 197: $1108-1116$

López-López I, Cofrades S, Cañeque V, Díaz MT, López O, JiménezColmenero F (2011) Effect of cooking on the chemical composition of low-salt, low-fat Wakame/olive oil added beef patties with special reference to fatty acid content. Meat Sci 89:27-34

Lourenço SO, Barbarino E, De-Paula JC, Pereira LODS, Lanfer Marquez UM (2002) Amino acid composition, protein content and calculation of nitrogen-to-protein conversion factors for 19 tropical seaweeds. Phycol Res 50:233-241

Martínez-Hernández GB, Castillejo N, Carrión-Monteagudo MM, Artés F, Artés-Hernández F (2017) Nutritional and bioactive compounds of commercialized algae powders used as food supplements. Food Sci Technol Int 24:172-182

Moreira R, Chenlo F, Torres MD, Rama B (2014) Fine particle size chestnut flour doughs rheology: influence of additives. J Food Eng 120:94-99

Overend R, Chornet E (1987) Fractionation of lignocellulosics by steamaqueous pretreatments. Phil Trans R Soc Lond A 321:523-536

Pérez-Santaescolástica C, Carballo J, Fulladosa E, Garcia-Perez JV, Benedito J, Lorenzo JM (2018) Application of temperature and ultrasound as corrective measures to decrease the adhesiveness in drycured ham. Influence on free amino acid and volatile compound profile. Food Res Int 114:140-150

Plaza M, Amigo-Benavent M, del Castillo MD, Ibáñez E, Herrero M (2010) Facts about the formation of new antioxidants in natural samples after subcritical water extraction. Food Res Int 43:23412348

Raymundo A, Fradinho P, Nunes MC (2014) Effect of Psyllium fibre content on the textural and rheological characteristics of biscuit and biscuit dough. Bioact Carbohydr Dietary Fibre 3:96-105

Re R, Pellegrini N, Proteggente A, Pannala A, Yang M, Rice-Evans C (1999) Antioxidant activity applying an improved ABTS radical cation decolorization assay. Free Radic Biol Med 26:1231-1237

Rupérez P (2002) Mineral content of edible marine seaweeds. Food Chem 79:23-26

Sánchez-Machado DI, López-Cervantes J, López-Hernández J, PaseiroLosada P (2004) Fatty acids, total lipid, protein and ash contents of processed edible seaweeds. Food Chem 85:439-444

Saravana PS, Choi JH, Park YB, Woo HC, Chun BS (2016) Evaluation of the chemical composition of brown seaweed (Saccharina japonica) hydrolysate by pressurized hot water extraction. Algal Res 13:246254

Shibata T, Ishimaru K, Kawaguchi S, Yoshikawa H, Hama Y (2008) Antioxidant activities of phlorotannins isolated from Japanese Laminariaceae. J Appl Phycol 20:705-711

Taylor VF, Li Z, Sayarath V, Palys TJ, Morse KR, Scholz-Bright RA, Karagas MR (2017) Distinct arsenic metabolites following seaweed consumption in humans. Sci Rep 7:3920

Wan P, Yang X, Cai B, Chen H, Sun H, Chen D, Pan J (2015) Ultrasonic extraction of polysaccharides from Laminaria japonica and their antioxidative and glycosidase inhibitory activities. J Ocean Univ China 14:651-662

WHO (2015). World Report on Ageing and Health. ISBN 9789241565042

Publisher's note Springer Nature remains neutral with regard to jurisdictional claims in published maps and institutional affiliations. 